\title{
Impact of Credit Risk Management on the Financial Performance of Selected Deposit Money Banks in Nigeria
}

\author{
Gideon Tayo Akinleye \\ Ekiti State University \\ Adeduro Adesola Ogunmakin \\ Ekiti State University \\ Ademoye Kehinde Tosin \\ Ekiti State University
}

The study examined the impact of credit risk management on the financial performance of selected deposit money banks in Nigeria. The study focused on 10 deposit money banks randomly selected from 21 deposit money banks listed on the Nigeria stock exchange as at 30th May, 2019. Data were collected from the annual reports of the selected banks over a period of 10 years. Single panel based model was used in the study. The result showed that loan and advances exert insignificant positive impact on return on asset, with reported coefficient estimate and probability value of 0.0006479 and $0.180>0.05$ ) respectively. Reported $R$-square for the pooled OLS estimation stood at 0.5276, which implies that credit risk variables including loan and advances and non-performing loan can only explain about 53\% of the systematic variation in return on asset. The study recommended that, Management of deposit money banks in Nigeria should be strategic when setting limits for loans and advances.

Keywords: credit risk management, loans and advances, non-performing loans, return on assets

\section{INTRODUCTION}

Traditional banking theories stated that lenders ought to broaden their risk, provided that in the course of subjoining their credit lines to other sectors, the bank's probability of default on credit facilities will be reduced (Mohammed, 2012). Banks should conduct sufficient due diligence to completely perceive the overall credit risks that exist both for individual and group loan. Prudent risk balloting is key to maintaining propitious lending quality. The purpose of risk management is to assess the likelihood of timely credit repayment. This process involves evaluating the steps banking institutions take to identify and control risk throughout the credit process. It involves the administration of credit facility to ensure orderly and full payment, monitoring of credit facilities as well as identifying strategies when credits actually deteriorate. Banks should not engage in a business that unnecessarily imposes risks upon them, nor should they imbibe chances that can be effectively transferred, but rather, they should accept risks that are uniquely part of the service rendered by the banks (UNDP, 2008). The financial systems of most developing nations have come under stress as a result of economic shocks (Brunner, 1982). Banks make 
for a vital part in a nation's economy through credit generation. Banks take savings from small and large depositors, give loans, operate payments systems, and provide a mechanism for the transmission of the monetary policy (Adewale, 2013).

The main objectives of any financial institutions to make profit and maximize shareholders' wealth. To this end, banks manage their credit risk by holding assets and attempting to maximize their return by way of increasing market interest rate, loans, cash demands and discount rate (Davidson \& Gabriel, 2009). Profitability performance concentrates on statement of income and expenditure which shows the amount of revenue a bank generates and how much it spent (expenses) net income. This may be prepared by the bank on a monthly, quarterly or annual basis (Codjia, 2010).

Business performance may well be determined in a number of ways which includes: Return on Assets (ROA) and Return on Equity (ROE) (Tennant, 2003). Effective credit management keenly requires the ability to intelligently manage customers' credit lines. In other words, to minimize exposure to bad debts and bankruptcy, firms must deeply know a customer's financial strength, full business details, credit score history and fluctuating payment patterns. Previous researchers prefer using Return on Assets (ROA) as a tool to measure performance. In theory, ROA shows the capacity of a bank's managers to make profits using the level of assets available (Athanasoglou, 2005).

Studies have been conducted to evaluate credit risk management and financial performance of banks both in developed and developing nations, but their findings reveal different results. For instance, Adewale (2013) analysed the relationship between credit risk management and banks' profitability, the study concluded that, banks' profitability is indirectly inclined by the level of loans and advances, and non- performing loans, thus posing the system financial risk of market volatility as well as distress. Likewise, Godlewski (2004) investigated the relationship between credit management and bank performance, the study concluded that, the performance of banks was adversely influenced by the level of non-performing ratio.

Similarly, Mohammed (2012) examined relationship between credit risk management and banks' performance and he concluded that unfitting credit risk management decrease banks' profitability and that it impacts the value of their resources and upsurge loan losses. Distinctively, to fill the gap in literature, this study intends to investigate the connection amongst credit risk management and profitability of deposit money banks in Nigeria. By using ROA as independent variable, while the dependent variable profitability of banks shall be proxied using loans and advances and non-performing loans

\section{LITERATURE REVIEW}

\section{Conceptual Literature}

\section{Credit Risk Management}

Credit Risk Management (CRM) involves the administration of credit facility to ensure orderly and full payment, monitoring of credit facilities as well as identifying strategies when credits actually deteriorate. Banks need not to involve in business in such manner that will needlessly inflicts risks upon them, nor should they absorb risks that can be effectively transferred to other participants, but rather, they should accept risks that are uniquely part of their array of services (UNDP, 2008). Banks should conduct sufficient due diligence to completely recognize the credit risks that exist both for individual loans and for the entire portfolio. Effective portfolio management begins with the omission of the risk in the individual loans. The purpose of portfolio management is to assess the likelihood of timely credit repayment. The historical emphasis on controlling the quality of individual loan approvals and managing the performance of loans continues to be essential (Ledgerwood, 2009).

\section{Relationship Between Credit Risk Management and Financial Performance}

Pandley (2005) defines credit risk management to involve the process, of making choices linking the venture of funds. Such choices need to be rigorously examined as they will be made from a component of uncertainty. Bessis (2008) identifies economic performance as initiative made by managers to advance the 
veracity and aptness of financial intelligence to meet required standards while supporting day to day operations.

Lymon\&Carles (2008) also defined it as the operational strength of a firm in relation to its revenue and expenditure as revealed by its financial statements in any organization commercial banks in particular, financial performance is affected by credit risk. The general role of bank continues to be essential in running economic output while its efficacy might function positively on financial system as a well-grounded banking system is better able to resist adverse shocks and lead to stability of an economic system. (Athanasoglou,2005). Therefore, the basis for performance of financial institutions have drawn the awareness of scientific research, also of bank and financial management since the knowledge of the internal and external determinants of banks' profits and margins is essential for various parties.

Achou\&Tenguh (2008) shows there is a major association amongst bank performance (in terms of return on asset) and credit risk management (in terms of loan advances). Enhanced risk management ends up in improved bank performance. Thus, it is truly of significance that banks exercise judicious credit risk management and maintenance of resources of the banks in order to safeguard the investors' interests. Banking institutions are some of the predominant financial institutions whose changes in performance and structure have far reaching implications on the whole economy (Bohnstedt, 2000). Banking institutions are engaged in a wide range of activities like investment, trading and banking which exposes them to risk. Therefore, the instability in financial performance especially in banking industry emanates from the poor credit risk management.

\section{Credit Performance in Banks}

Credit can positively or negatively influence the rate of economic activity through its influence on capital accumulation. This is often correct for developing countries where capital markets are still in infancy (AFDB, 2008). One of the biggest challenges facing banks is the large stock of non-performing advances. The poor state of loan portfolios in deposit money banks have been a major cause of insolvency in Nigeria and the large stock of non-performing assets (NPA) is threatening macroeconomic stability. It has deprived the economy of a continuous flow of funds to economically viable activities, and this has had adverse effects on the progress and expansion of Nigeria's financial services. Poor asset quality does not only hinder a deposit money bank's ability to recycle its financial resources, it also threatens its viability. Deposit money banks in Nigeria have registered a high assets loss and if not checked, could result in the loss of confidence in banks sub-sector of the financial industry. For money deposit banks to be successful, they must manage their credit function efficiently and effectively. How effectively a financial institution manages its credit function is the basis on which its quality of assets and performance are judged (Mueller, 2003).

\section{Profitability of Banks}

Banking Profitability may also show managers attitude toward risk. Banks that make huge profits are not scared when venturing into risky activities. Profitability measure is important to the investors. The extent of productivity is very substantial which is intended for the shareholders of a bank, since it is a demonstrations of how operational managements have applied their capital (Devinaga, 2010). In defining the economic strength of a commercial bank, the level of profitability is predominant. According to Codjia (2010), profitability performance will concentrate on the income statement which shows how much is generated (revenue) and how much is spent (expenses) net income. This may be prepared by the bank on a monthly, quarterly or annual basis (Codjia, 2010). According to Rushdi and Tennant (2003), profitability is calculated in many ways. These include Return on Assets (ROA), Return on Equity (ROE). But over the years, most researchers have employed the use of Return on Assets (ROA). Godlewski (2004) used ROA in measuring profitability. It was disclosed that; the performance of a bank was adversely influenced by the extent of non-performing ratio. In theory, ROA shows the capacity of a bank's management to make profits using the level of assets available. It may be unfair because of the other events that take place outside the statement of financial position (Athanasoglou 2005). 


\section{Financial Performance Measures}

Bessis (2008) describes financial performance as an administration resourcefulness to advance the veracity and aptness of financial evidence to meet required standards while supporting day to day operations. Lyman and Carles (2008) also defines it as the operational strength of a firm in relation to its revenue and expenditure as revealed by its financial statements. Financial performance is characterized by a bad debt policy, sales turnover, profitability level, client's dropout rate, growth, reduction in fixed assets, and physical visitation by commercial staff, debt age analysis, and public media. Generally, the financial performance of banks and other financial institutions have been measured using a combination of financial ratios analysis, benchmarking, measuring performance against budget or a mixture of these research methods (Avkiran, 2005). Simply stated much of the current bank performance. Chien and Danw (2004) indicate that previous researches in relation to business performance assessment center just on working effectiveness and operational efficiency, which might unswervingly guide the existence of a business. By means of state-of-the-art two-stage statistics envelopment analysis model in their study, the empirical result of this study is that a company with better efficiency does not always mean that it has better effectiveness.

\section{Theoretical Review}

\section{Credit Risk Theory}

Cantor and Frank (1996) posited that credit risk theory is the first voluntarily accessible portfolio model for estimating credit danger. The credit risk method assists a company to merge credit risk through its whole organization as well as offers a statement of value-at-risk owing to credit initiated by upgrading, downgrading and defaulting. Credit risk model is useful to all firms that are exposed to credit risk in the path of their business. According to this theory as stated by Padilla and Pagano (2000), a firm should develop a method of quantifying credit risk through a comprehensive variety of tools as well as traditional loans, fixed income instruments; commercial contracts such as trade credits and receivables; commitments and letters of credit; and market-driven instruments such as swaps, forwards and other derivatives

Powell(2004) explained that credit risk statistical concepts such as probability, means, standard deviation and correlation were developed with three objectives which include to develop a value-at-risk framework that is applicable to all the institutions worldwide that are involved in credit risks during the progress of their businesses, develop a portfolio view showing the credit event correlation that may isolate the overheads of concentrations, and the advantages of diversification in a mark to market framework and to apply it in making investment decisions, and risk mitigating actions that are determining the risk based credit limits across the portfolio and rational risk based capital allocations. The firm should have an integrated credit risk management system for assessing portfolio risk due to changes in debt value caused by changes in obligating credit quality (Rajan, 1995).

Prakash and Poudel (2012) believed that there are various applications which are to reduce the portfolio risk by reevaluating obligations with the largest absolute size. They argued that a single default among these would have the greatest impact, reevaluate obligations with the highest percentage level of risk. They held that these would most likely contribute to portfolio losses, reevaluate obligations as well as contribute to the largest absolute amount of risk. In their opinion these are the single largest contributors to portfolio risk.

\section{Credit Risk Modeling}

Stiglitz and Weiss (1981) projected that credit risk management can be a very analytical and statistical process. Theoretical models used to estimate and manage credit risk are often complex and highly quantitative. It must be emphasized that before credit risk can be well managed, it must first be measured. Davidson (2009) considers the two broad approaches to credit risk analysis: classical option pricing models and direct modeling of the default probability of issuers. Insights offered can be drawn from each approach with demonstration that the distinction between the two approaches is not at all clearcut. 
Walsh (2010) revealed in his approach that the model strikes a fruitful balance by quickly presenting the basic philosophies of the prototypes and rendering sufficient details so that firms wishing to implement this model will develop and apply the models themselves. Jose and Riestra (2002) stated that credit risk model is used by firms to measure and manage credit risk thus, the model serve three main functions which are: the models are used to estimate the possibility that other party will default or fail to pay what it owes; the model needs to be able to measure the dollar amount that might be lost if a counterparty defaults and the model should have the capability to measure the connection of nonpayment risks across the entire credit exposure to manage portfolio. As such, the models are envisioned to help financial institutions in computing, accumulating and handling risk through environmental and product ranks.

The yields of these models also show aggregate and important roles in risk management and the performance measurement processes of financial institutions and manufacturing firms comprising performance-based reward, client profitability exploration, risk-based valuing and dynamic portfolio administration and capital arrangement choices. Credit risk modeling may certainly demonstrate enhanced internal risk management results and may have the prospects to be used in the managerial inaccuracy of financial institutions.

\section{Empirical Review}

Abiola and Olausi (2014), analyzed the effect of credit risk management on the performance of Deposit Money Banks in Nigeria. The study employed panel regression analysis technique. ROE, ROA i.e returns on equity \& Capital respectively were used to proxy performances while NPL, CAR i.e nonperforming loan and capital adequacy ratio were used as proxies for credit risk management. The study showed that there is a significant relationship between credit risk management and profitability of commercial banks in Nigeria. The study recommends that commercial banks with greater CAR can well spread more loans and enthrall credit losses whenever they arise and so record enhanced profitability. The governing authority must pay more attention to banks' compliance to relevant provisions of the Bank and other Financial Institutions Act 1991 and prudential guidelines.

Also, Tafri (2015) examined the effect of credit risk on performance of the conventional and Islamic banks in Malaysia between the periods from 1996 to 2005. The "proportion of allowance for the loan loss to total assets" was used to represent the credit risk. The study used regression analysis method and found a significant correlation amongst credit risk and profitability. Thus, it was emphasized that profitability as an "ultimate" test for the effectiveness of risk management.

Wakaria (2016) investigated the effect of credit management on performances of micro-finance banks in Kenya for the period of five years spanning from 2011-2015. Data for the study were sourced from both deposit taking and non-deposit taking micro finance institutions in Kenya. The study employed credit risk, liquidity risk and interest rate risk as proxies for credit management while ROE was used to proxy performance. The study showed a negative relationship between credit risk and ROE. The study recommended that the microfinance institutions in Kenya must pay constant attention to credit risk being a major risk to non- performing loans.

Similarly, Onuara and Ifeacho (2017) studied the effect of credit management on the profitability of manufacturing firm using five quoted firm in Nigeria stock exchange for a period 2010-2014. The data sourced from annual report of selected companies was analysed using descriptive statistics and the pooled multiple regression. The result revealed that credit policy and liquidity management has significant adverse correlation to ROA while debtors' turnover has significant positive effect to ROA.

\section{RESEARCH METHOD}

This study employed the use of secondary data, which were sourced from the annual reports of the selected banks Nigeria. The population for the study is twenty-one (21) existing deposit money banks in Nigeria. Ten (10) banks were randomly selected from the population. The selected banks are First Bank Plc, Guaranty Trust Bank Plc, Zenith Bank Plc, Union Bank Plc, Wema Bank Plc, Sterling Bank Plc, 
Diamond Bank Plc, Fidelity Bank Plc; United Bank for Africa Plc and Access Bank Plc. The study covered 10 years, spanning from 2008 to 2017.

\section{Model Specification}

This study adopted the model of Kolapo, Ayeni and Oke (2012), they studied "Credit Risk and the Performance of Nigerian Banks" and their study measured profitability with Return on Assets (ROA) as a function of Bank Reserve (BR), Total Assets (TA), Non-Performing Loan (NPL), Interest Rate (IR) and Total Debt (TD)

$\mathrm{ROA}_{\mathrm{it}}=\alpha_{0}+\alpha_{1} \mathrm{BR}_{\mathrm{it}}+\alpha_{2} \mathrm{TA}_{\mathrm{it}}+\alpha_{3} \mathrm{NPL}_{\mathrm{it}}+\alpha_{4} \mathrm{IR}+_{\mathrm{it}} \alpha_{5} \mathrm{BD}_{\mathrm{it}}+\mathrm{e}$

where:

$$
\begin{array}{ll}
\text { ROA } & =\text { Return on Asset } \\
\alpha_{0}-\alpha_{2} & =\text { Coefficients } \\
\text { BR } & =\text { Bank Reserves } \\
\text { TA } & =\text { Total Asset } \\
\text { NPL } & =\text { Non Performing Loans } \\
\text { IR } & =\text { Interest Rate } \\
\text { BD } & =\text { Bank Deposits } \\
\text { e } & =\text { error term } \\
\mathrm{i} & =\text { cross sections i.e banks } \\
\mathrm{t} & =\text { years }
\end{array}
$$

However, the study re- modified the model by incorporating different variables like Non-Performing Loan (NPL) and Provision for Doubtful Debts (PDD) as indicators of credit risk management. This is backed up by the plethora of evidence given in various literatures and theoretical framework that underlies the concept of credit risk management. In respect of this, the model that is aimed at determining the level of credit risk management with profitability to the Nigerian deposit money banks is given below:

$\mathrm{ROA}=\mathrm{f}(\mathrm{NPL}, \mathrm{PDD}, \mu)$

This model for the purpose of simplicity can be stated in equation terms as depicted below: -

$\mathrm{ROA}=\delta+\alpha \mathrm{LA}+\chi \mathrm{NPL}+\mu \ldots$ (II)

where:

$\begin{array}{ll}\text { ROA } & \text { - Return on Assets } \\ \text { LA } & \text { - Loans and Advances } \\ \text { NPL } & \text { - Non-Performing Loan } \\ F & \text { - Funtional Notation } \\ \mu & \text { - Error Term } \\ \alpha \text { and } \chi & \text {-Coefficients of Estimates }\end{array}$

To avoid spuriousity in estimation, the model can also be stated in it log-linearized form as depicted below:

$\log (\mathrm{ROA})=\delta+\alpha \log (\mathrm{INV})+\chi \log (\mathrm{NCA})+\mu$

where: Log - Natural Logarithm

From equation III above, the model can further be stated in time series form as depicted below: 
$\log (\mathrm{ROA})_{\mathrm{t}}=\delta+\alpha \log (\mathrm{NPL})_{\mathrm{t}}+\chi \log (\mathrm{PDD})_{\mathrm{t}}+\mu$

\section{Estimation Techniques}

This study adopts Constant and Fixed panel data analysis, which is prone to spuriousity of result and short-run, oriented to test the relationship between the explanatory variables and dependent variables of ten (10) selected deposit money banks in Nigeria.

\section{RESULT AND DISCUSSIONS}

TABLE 1

DESCRIPTIVE ANALYSIS

\begin{tabular}{|c|c|c|c|c|c|}
\hline Variable & Obs & Mean & Std. Dev. & Min & Max \\
\hline ROA & 100 & 1.677088 & 2.522939 & -9.2741 & 13.96257 \\
\hline LA & 100 & 647.8562 & 541.2901 & 0 & 1972.544 \\
\hline NPL & 100 & 225.4861 & 254.1473 & 0 & 804.5566 \\
\hline
\end{tabular}

Note: ROA=Return on Asset (\%), LA=Loan and Advances (billion naira), NPL=Non-performing loan (billion naira)

Source: Author's Computation, (2019)

Table 1. showed average return on asset stood at $1.67 \%$, with minimum and maximum values of about $-9.27 \%$ and $13.96 \%$. Average loan and advances stood at 647.8562 billion naira, with minimum and maximum values of 0 and 1972.544 billion. Average non-performing loan for the period covered in the study across firms selected stood at 225.4861 billion, with minimum and maximum values of 0 and 804.5566 billion. Measure of dispersion of observation from the mean values (i.e standard deviation) stood at 2.522939, 541.2901 and 254.1473for return on asset, loan and advances and non-performing loan respectively.

TABLE 2

\section{CORRELATION STATISTICS}

\begin{tabular}{|c|l|l|l|l|}
\hline & ROA & LA & NPL & PDD \\
\hline ROA & 1.0000 & & & \\
\hline LA & 0.1465 & 1.0000 & & \\
\hline NPL & 0.0109 & 0.1699 & 1.0000 & \\
\hline
\end{tabular}

Source: Author's Computation, (2019)

Table 2, revealed existence of positive correlation between return on asset and loan \& advances, return on asset and non-performing loan. The result showed that return on asset moves predominantly in the same direction with loan and advances as well as with non-performing loansIn specific terms correlation statistics stood at 0.1465 and 0.0109 for ROA and LA, ROA and NPL respectively.

TABLE 3

POOLED OLS ESTIMATION RESULT SERIES: ROA LA NPL

\begin{tabular}{|c|c|c|c|c|}
\hline Variable & Coefficient & Std Error & T-Test & Probability \\
\hline C & 1.423684 & 0.4828198 & 2.95 & 0.004 \\
\hline LA & 0.0006479 & .0004799 & 1.35 & 0.180 \\
\hline NPL & 0.0001223 & .0010715 & 0.11 & 0.909 \\
\hline
\end{tabular}

$R$-square $=0.5276$, Adjusted R-square $=0.5028$, F-statistics $=10.91$, Prob(F-stat $)=0.0097$

(*) connotes significance at $5 \%$ level of significance.

Source: Author's Computation, (2019) 
Table 3 revealed the impact of credit risk management variables on return on asset of the selected banks, when uniqueness across the banks is not incorporated into the model. Result showed that loan and advances exert insignificant positive impact on return on asset, with reported coefficient estimate and probability value of 0.0006479 and $0.180>0.05)$ respectively. Non-performing loan exert insignificant positive impact on return on asset, with coefficient estimate of $0.0001223(\mathrm{p}=0.909>0.05)$. Reported Rsquare for the pooled OLS estimation stood at 0.5276, which implies that credit risk variables including loan and advances and non-performing loan can only explain about $53 \%$ of the systematic variation in return on asset, when heterogeneity effect across sampled deposit money banks is incorporated into the model.

TABLE 4

FIXED EFFECTS ESTIMATES (CROSS-SECTIONAL AND PERIOD SPECIFIC) SERIES: ROA LA NPL

\begin{tabular}{|c|c|c|c|c|c|}
\hline \multicolumn{3}{|c|}{ CROSS-SECTIONAL SPECIFIC EFFECT } & \multicolumn{3}{|c|}{ TIME SPECIFIC EFFECT } \\
\hline Variables & Coefficients & Prob & Variables & Coefficients & Prob \\
\hline $\mathrm{C}$ & 1.490154 & 0.127 & $\mathrm{C}$ & 1.023859 & 0.193 \\
\hline LA & .0006116 & 0.338 & LA & .0004826 & 0.373 \\
\hline NPL & -.0028642 & 0.291 & NPL & .0001715 & 0.867 \\
\hline PDD & -.0017933 & 0.972 & PDD & -.0235795 & 0.330 \\
\hline Effects & & & Effects & & \\
\hline DIAMOND BANK & .5653603 & 0.717 & 2009 & .8041157 & 0.458 \\
\hline FIRSTBANK & -.3118978 & 0.787 & 2010 & 1.322502 & 0.224 \\
\hline GTB & 1.579608 & 0.193 & 2011 & -.8038242 & 0.463 \\
\hline FCMB & .5759174 & 0.642 & 2012 & 2.443799 & 0.029 \\
\hline UBA BANK & 1.595261 & 0.429 & 2013 & -1.76912 & 0.112 \\
\hline UNION BANK & -.203596 & 0.896 & 2014 & .974513 & 0.389 \\
\hline ZENITH BANK & 2.113719 & 0.264 & 2015 & .9012731 & 0.439 \\
\hline WEMA BANK & -1.903271 & 0.104 & 2016 & .9646873 & 0.416 \\
\hline FIDELITY BANK & .5439695 & 0.675 & 2017 & 6723248 & 0.574 \\
\hline \multicolumn{3}{|l|}{$\begin{array}{l}\text { R-square }=0.5370 \\
\text { Adjusted R-square }=0.5180 \\
\text { F-statistics }=11.15 \\
\text { Prob(F-stat })=0.0010\end{array}$} & \multicolumn{3}{|c|}{$\begin{array}{l}\text { R-square }=0.7205 \\
\text { Adjusted R-square }=0.7129 \\
\text { F-statistics }=2.05 \\
\text { Prob(F-stat) }=0.0288\end{array}$} \\
\hline
\end{tabular}

Sources: Author's Computation, (2019)

Table 4, showed that when heterogeneity effect across the sampled deposit money banks is incorporated into the model as intercept term, impact of loan and advance on return on asset remained positive and insignificant, with coefficient estimate of $0.0006116(p=0.338>0.05)$. On the other impact of non-performing loan on return on asset became negative but insignificant, with reported coefficient estimate which stood at $-0.0028642(\mathrm{p}=0.291>0.05)$. R-square value reported for cross-sectional specific estimation presented in table 4.4 stood at 0.5370 , which reflect that about $54 \%$ of the systematic variation in return on asset can be explained jointly by loans and advances and non-performing loan

Estimation result presented in table 4.4 for fixed effect period-specific revealed that when heterogeneity effect over the period covered in the study was incorporated into the model as intercept term, impact of loan and advance remain positive and insignificant $.0004826(\mathrm{p}=0.373>0.05)$, impact of non-performing loan also positive and insignificant $0.0001715(\mathrm{p}=0.867>0.05)$. Reported R-square statistics showed that about $72 \%$ of the systematic variation in return on asset can be explained jointly by loan and advances and non-performing loans. 
Deviation from the intercept term (1.490154) corresponding to the reference bank (Access Bank Plc) stood at $0.5653603,-0.3118978,1.579608,0.5759174,1.595261,-0.203596,2.113719,-1.903271$, 0.5439695 for Diamond Bank Plc, First Bank Plc, Guaranty Trust Bank Plc, First City Monument Bank Plc, United Bank for Africa Plc, Union Bank Plc, Zenith Bank Plc, Wema Bank Plc, and Fidelity Bank Plc respectively. Also deviation from the intercept term (1.023859) of the reference period (2008) stood at $0.8041157,1.322502,-0.8038242,2.443799,-1.76912,0.974513,0.9012731,0.9646873$ and 0.6723248 for $2009,2010,2011,2012,2013,2014,2015,2016$ and 2017 respectively.

\section{CONCLUSION AND RECOMMENDATIONS}

Based on this finding, the study concluded that, credit risk management measured in terms of loans and advances and non-performing loan had positive and significant impact on financial performance of deposit money banks in Nigeria. The study recommended that, Management of deposit money banks in Nigeria should be strategic when setting limits for loans and advances, because excessive increase of loan and advances might do more harm than good. This is because increase in loan and advance as strategy for credit risk management does not reflect significant influence on the level of profitability.

\section{REFERENCES}

Abiola, I., \& Olausi, A.S. (2014). The Impact of Credit Management on the Commercial Banks Performance in Nigeria. International Journal of Management and Sustainability, 3(5), 292-306.

Adewale, T. P. (2013). Credit and Growth of Economic Activityin Nigeria: An Empirical Investigation. Nigerian Journal of Banking and Financial, 1(2), 4- 13.

Anyanwu, J.C. (2003). Monetary Economics: Theory, Policy and Institutions. Benin City. Hybrid Professional Publishers Ltd, Central Bank of Nigeria: Statistical Bulletin (Various Editions). Abuja. Central Bank of Nigeria: Annual Reports. (Various Editions). Abuja.

Athanasoglou, P.P. (2011). Bank Capital and Risk in the South Eastern European Region. Bank of Greece Working Paper, No. 137. DOI: 10.2139/ssrn. 1774585.

Athanasoglou, P.P., Brissimis, S.N., \& Delis, M.D. (2005). Bank-Specific,Industry-Specific and Macroeconomic Determinants of Bank Profitability. International Journal of Banking Finance, $18(2), 121-136$.

Codjia. (2010). Credit Management Practices in developed countries and Nigeria experience. Eldota Ventures Limited, Lagos

Davidson, A.S., \& Gabriel, T. (2009). Historical return on Real Estate Investment. Journal of Portfolio Management, 2(3), 4-20.

Devinaga, R. (2010). Theoretical Framework of Profitability as Applied to Commercial Banks in Malaysia. European Journal of Economics, Finance and Administrative Sciences, 1(9), 76-87.

Godlewski, A.Y. (2004). Determinants of commercial bank interest margins and profitability. World Bank Economic Review, 13, 379-408.

Kolapo, T.F., Ayeni, R.K., \& Oke, M.O. (2012). Credit Risk and commercial bank's Performance in Nigerian: A Panel Model Approach. Australian Journal of Business and Management Research, 2(2), 31-38.

Ledgerwood, J. (2009). Microfinance Handbook. An Institutional and Financial Perspective, pp. 21-26.

Mohammed, M.O. (2012). Comparative Analysis of the Performance of Residential Property Investment and Investment in Securities in Lagos Nigeria. The Estate Surveyor and Valuer, 26(1), 7- 14.

Muellar, J. (2003). The importance of saving and Poverty eradication in rural areas of Uganda. Quarterly Review on Saving Culture, 12(4), 12-20.

Pandley, I.M. (2005). Financial Credit Management. Vicar Publishing House, New Delhi.

Poudel, R.P. (2012). The impact of credit risk management on financial performance of commercial banks in Nepal. International Journal of Arts and Commerce, 1(5), 9-15. 